\title{
The Purpose of the Symposium
}

There are two purposes of this symposium. One is to discuss ecology, maintenance and management of the humid evergreen forests dominated mainly by evergreen oak, laurel and red wood families, and to seek the co-existence of people with those forests. The other is to set up a network of Biosphere Reserves in the East Asia and the Pacific region.

In December 1993, Yakushima Island, Kagoshima Prefecture, was registered as a World Natural Heritage Site. It includes three main ecosystems such as lucidophyll oak-laurel forest, Japanese cedar (Cryptomeria japonica) forest and dwarf bamboo grassland. In commemoration of the registration of Yakushima Island as a world natural heritage site, the Kagoshima University holds an international symposium on "Co-existence of the World Humid Evergreen Forest Ecosystems and People - from Yakushima Island, Kagoshima, a World Natural Heritage Site -", from 19 to 25 October, 1996 at Kagoshima University and in Yakushima Island including discussion in the field.

Lucidophyll oak-laurel forests are found not only in a corridor from south facing slope of the Himalayas to SW Japan through S China and Taiwan but also in the Canarias Islands, SE of N America, and commonly in the higher altitudes in the tropical Asia. They are composed mainly of Fagaceae, Lauraceae, Theaceae, and Hamamelidaceae. Timbers of Taxodiaceae are useful for many purposes, and so forests of Taxodiaceae have been under a heavy control by the people who developed various ways of sustaining and management system of the forest. We must learn these traditional ways of forest management.

Yakushima Island is one of the four Biosphere Reserves in Japan, which were authorized in 1980 by UNESCO. In the east Asian region there are 17 Biosphere Reserves authorized by UNESCO. Networking of Biosphere Reserves has been one of the main focal points in the UNESCO's Man and the Biosphere (MAB) Programme. In the East Asian region, Peoples' Republic of China, Republic of Korea, Japan, Mongolia and Democratic Peoples' Republic of Korea have been co-operating for establishing the East Asian Biosphere Reserves Network (EABRN) since 1993. They had already three meetings for this purpose, twice in China and once in Korea, and at the same time they cooperated to evaluate activities in two Biosphere Reserves in China and one Biosphere Reserve in Korea by specialists who are actively taking part in MAB Programme in these countries.

Representatives of MAB Programme from the East Asian countries discussed to co-operate in various ways to have a network of Biosphere Reserves in the region for enhancing activities in and effective use of Biosphere Reserves. They agreed to have the fourth meeting in Japan. The Japanese National Committee for MAB made a plan to hold the meeting in Kagoshima University and Yakushima Island, 19-25 October 1996 in close contact with UNESCO Jakarta Office as special session of this symposium. In addition to delegates from the East Asian countries, participations of delegates are expected from other countries in Asia and the Pacific region for expanding the network of Biosphere Reserves to the Asia-Pacific.

Hideo TAGAWA Prof. emer. Kagoshima University President of Kagoshima Prefectural College 


\section{An International Symposium: Co-existence of the World Humid Evergreen Forest Ecosysems and People}

-From Yakushima Island, Kagoshima, a World Natural Heritage Site-October 20 (Sunday), Inamori Auditorium of Kagoshima University

\section{Opening session}

The purpose and significance of World Natural Heritage. L. F. Molloy

Session 1 Ecology and management of evergreen oak-laurel forests and co-existence of the forests with people

01 World-wide distribution of evergreen oak-laurel forests. H. Tagawa

02 Patterning of subtropical and warm-temperate evergreen broad-leaved forests in East Asian mountains with special reference to shoot phenology. M. Ohsawa and I. Nitta

03 Type, structure, dynamics and management of the lower subtropical evergreen broad-leaved forest of Dinghushan Biosphere Reserve of China. Kong G. H., Huang Z. L., Zhang Q. M., Liu S. Z., Mo J. M., and He D. Q.

04 Mid-mountain moist evergreen broad-leaved forest ecosystem of Yunnan, China and its preservation. Xie S. C.

05 Biodiversity and conservation of the evergreen broad-leaved forests in Taiwan. Hsieh C. F. and Lai I. L.

06 Laurel forest in the Canary Island: biodiversity, historic use and conservation. W. W. de la Torre and V. E. Martín Osorio

07 Dynamics of primary and secondary warm-temperate rain forest in Yakushima Island. T. Kohyama.

08 Management of Podocarpaceae and Nothofagus forests of New Zealand for nature conservation and tourism. L.F. Molloy

09 Some ecological features and traditional way of maintenance and management system of evergreen broad-leaved forest in South Korea including Chejudo. Yim Y. J.

\section{October 21 (Monday), Inamori Auditorium of Kagoshima University}

Session 2 Ecology and management of conifer forests dominated by Taxodiaceae and co-existence of the forests with people

10 Phytogeographic history of the Taxodiaceae and importance of preserving mixed broad-leaved deciduous evergreen forest. H. Nishida

11 The dynamics of natural Cryptomeria forest on Yakushima Island. E. Suzuki

12 Management of Sequoiadendron giganteum and Sequoia sempervirens forests in the reserves of California - Considerations of ecology and conservation. D. M. Graber

13 Recurrence interval of shallow landslide on forested steep slope in Yakushima Island. E. Shimokawa \& T. Jitozono

14 Relationship between plants and animals on seed dispersal in broad-leaved ever-green forest. N. Noma

15 Traditional way of forest management on Yakushima Island. I. Haraguchi

16 Damages on the farm products by wild animals and animal management in Yakushima Island. M. Manda

17 Economy of Yakushima and natural environment. Y. Takahashi

Session 3 Reports on MAB activities and discussion of biosphere reserves network

\section{October 22-24, Yakushima}

Session 4 Field observation and discussion

Session 5 Evaluation of Yakushima Biosphere Reserve and future co-operative activities in the AsiaPacific region 